\title{
Dans les derniers numéros des AHRF :
}

\section{(2) OpenEdition}

1 Journals

Édition électronique

URL : https://journals.openedition.org/ahrf/8753

DOI : $10.4000 /$ ahrf.8753

ISSN : $1952-403 X$

\section{Éditeur :}

Armand Colin, Société des études robespierristes

\section{Édition imprimée}

Date de publication : 1 mars 2007

Pagination : 193

ISSN : 0003-4436

\section{Référence électronique}

«Dans les derniers numéros des AHRF : », Annales historiques de la Révolution française [En ligne], 347| janvier-mars 2007, mis en ligne le 21 juillet 2008, consulté le 23 avril 2022. URL : http:// journals.openedition.org/ahrf/8753 ; DOI : https://doi.org/10.4000/ahrf.8753

Ce document a été généré automatiquement le 23 avril 2022.

Tous droits réservés 


\section{Dans les derniers numéros des} AHRF :

\section{BIBLIOGRAPHIE}

Danielle GALLET (éd.), Dans l'ombre de Marie-Antoinette. Le journal de madame Brunyer, 1783-1792 (G. Mazeau), n²005-2, p. 180.

Dena Goodman (ed.), Marie-Antoinette, Writings on the Body of a Queen (G. Mazeau), n²003-4, p. 184-187.

MARIE-ANTOINETTE, Correspondance. 1770-1793 (Michel Biard), nº 2006-2, p. 256-257.

Michèle SAPORI, Rose Bertin, ministre des modes de Marie-Antoinette (J. Bernet), n 2005-2, p. 180-181. 